\title{
THE SANDF AS A HUMAN SECURITY INSTRUMENT POST-1994
}

\author{
Thuso Benton Mongwaketse \\ Department of Political Sciences \\ University of Pretoria
}

\section{Abstract}

South Africa adopted a human security orientation at the start of its democratic epoch in 1994, but its operationalisation by the South African National Defence Force (SANDF) proved difficult to implement. Human security is an approach to security which prioritises the protection of the people over security of the state. One of its central tenets is that security is best achieved through development as opposed to arms. Against this backdrop, the principal objective of this article is to critically analyse and understand South Africa's official human security orientation. Two indicators, the functions performed by the SANDF as well as South Africa's strategic defence posture, were assessed to achieve the objective. The securitisation model associated with Barry Buzan and Ole Wæver was used as a theoretical framework to understand South Africa's official conception and utilisation of human security.

It was found that the SANDF's operational functioning was compromised by having to perform its primary responsibilities along with secondary developmental tasks demanded by the broad mandate of human security. Furthermore, while South Africa lexically took human security and state security to be equally important, in practice the SANDF tended to prioritise state security ahead of human security both at home and abroad. Some analysts detected lack of strategic coherence in South Africa's security engagements in Africa while ignoring extensive efforts of the SANDF to bring peace, and not destabilisation, on the continent as part of the strategic defence posture. Ultimately, this article argues that the competency with which the SANDF ensures 
state security must be cascaded down to the human level by taking up more secondary functions with some provisos. Alignment of defence policy and adequate resources as well as the involvement of the people will be indispensable towards realisation of true human security.

\section{Introduction}

The provision of security to the state and its people is the raison d'être of any government. Since the dawn of democracy in South Africa, government has promoted the notion of human security as the sine qua non of its security output as affirmed by then Minster of Defence, Mosiuoa Lekota (2008). The latest Defence Review notes that South Africa is "stricken by chronic underdevelopment, inadequate health services and the attendant problem of poverty, illiteracy and unemployment. These human security and development problems continue to impact negatively on the region [Africa] in the form of a range of nonmilitary threats" (RSA 2014: 1-5). While language and underlying principles of human security resonated with policymakers, South Africa's military apparatus found it difficult to operationalise the concept (Ferreira and Henk 2009: 519).

Apart from diagnosing contemporary security challenges, Africa (2015: 186) observes that the aforementioned Defence Review also makes a clarion call for all state institutions to be involved in mitigating strategies. This implies that besides traditional functions of a military entity - maintaining national sovereignty and securing territorial integrity - a state security organ like the South African National Defence Force is now expected to respond to other national goals. These include "the well-being, prosperity and upliftment of the South African people, the growth of the economy, and demonstrable good governance" (RSA 2014: V). Incumbent Minister of Defence, Nosiviwe Mapisa-Nqakula (2016), alludes to the broad nature of the SANDF's mandate when she says it is in "national interest to have a Defence Force capable of supporting national security imperatives, foreign policy objectives and the country's economic interests".

Despite security ostensibly being about and for the people under the human security framework as will be elaborated later, the daily lived experience of South African tells a different narrative. According to Southall (2010: 80-81), "up to $40 \%$ of South Africans have minimal prospect of increasing their human security (access to enough food, hous- 
ing, employment etc)". Southall attributes this problem to looming crises in the interrelated domains of politics, economics, human security and ecology. With this context and against the backdrop of South Africa's emerging security paradigm in the post-apartheid epoch, this article aims to analyse and assess how the SANDF has been used as an instrument of human security since 1994. Coming from the historic deposit of a military that was used primarily to guarantee state security during apartheid, it is vital to discern the socio-political and developmental impact of the SANDF in a democratic society.

Two specific and fundamental questions can be asked in order to achieve the set objective. What impact has the notion of human security as perceived by the South African government and the Department of Defence (DoD) had on the functioning of the SANDF since 1994? Secondly, what did these official perceptions of human security mean for the priority given to state security by the SANDF?

The questions could be answered by considering that state actors often understand and use the idea of human security in two distinct but related ways, that of lexis and praxis (Rozborová 2013: 2). Praxis refers to concrete political actions while lexis relates to what is said or written about human security. Rozborová (2013: 35) adds that when used as a political strategy "human security has the power to shape political discourse, political decisions, and it can consequently become a component or a leading strategy of a concrete political action". In sum, this article will scrutinise the lexis as largely expressed by the policymaking government and the $\mathrm{DoD}$, as well as the praxis of the policy executing SANDF.

\section{South Africa's redefinition of security}

The SANDF's endorsement of human security is consistent with Heinecken's (2006: 27) proposition that the changing global environment has a tendency to influence "how militaries function, the services they provide and to whom". Indeed, it is in this spirit of "profound political and strategic consequences" which included the almost simultaneous end of the Cold War and apartheid that new security policies congruent with human security were formulated in South Africa (RSA 1996: 4). 'Traditional security' concerns are generally ascribed to the period before the end of the Cold War. This realist inspired conception of security narrowly focused on military strategy and the use of force by states to 
deal with external threats (Mutimer 2008: 35; Snyder 2008: 3). It was this state-centric security orientation that remained dominant until there was a change brought about by the emergence of human security, more accurately under the auspices of critical security studies.

The broad nature of security and human security in particular gained prominence following the seminal Human Development Report of the United Nations Development Programme (UNDP) in 1994. The UNDP (1994: 3) explicates that:

For too long, the concept of security has been equated with the threats to a country's borders. For too long, nations sought arms to protect their security. For most people today, a feeling of insecurity arises more from worries about daily life than from the dread of a cataclysmic world event. Job insecurity, security from crime - these are the emerging concerns of security over the world.

The above citation illustrates a policy movement from security of the state towards security of the people and their development. From job security to crime, these and many more socio-economic challenges are the issues South Africa is grappling with within the broadened nature of security. The UNDP (1994: 24) explains that the security problematic now entails seven other sectors besides the military. These are the health, economic, food, personal, political, environmental, and community sectors. It thus appears like the emergence of human security diminishes the utility value of the military as an instrument for governments to pursue their security objectives.

One of the indications that a democratic South Africa was to adopt a human centric security approach can be found in policy proposals of a conference the African National Congress (ANC) held as it anticipated taking over the reins of power. The conference was jointly organised with the Institute for a Democratic Alternative for South Africa in Zambia in 1990 under the theme "The future of security and defence in South Africa". The ANC's security policy proposals were anti-militarist and biased towards socio-economic needs of the people. As John Nkadimeng, an ANC delegate, intimated, "the ultimate objective of our society should not be to build more barracks but more schools and hospitals. It should not be to manufacture more AKs and R1s [rifles] but more tennis rackets and golf clubs. Not more tanks and Hippos [military vehicles] but more tractors and harvesters" (cited in Nathan 1991: 5). Similarly, the reorientation of security was affirmed by Joe Nhlanhla in 
1992. Nhlanhla (cited in Seegers 2010: 272) who was to become the Minister of Intelligence (1999-2000) in the cabinet of ANC government said:

The redefinition of South Africa's security needs and interrelationship between security of the state and that of the people must be seen in arriving at a new definition of national security. The security of the state depends on its ability to maintain its political independence, sovereignty and territorial integrity. The security of the people depends on the satisfaction of their political, economic, cultural, and social needs. The security of the state depends on the security of the people and security of the people depends on the security of the state.

It can be deduced that the ANC intended to strike a balance between state security and human security instead of prioritising one at the expense of the other. Furthermore, it can be enunciated that the postapartheid government identified with the UNDP (1994: 24) framework of "freedom from fear" and "freedom from want" as the central components of human security. Further reading of the UNDP report reveals that freedom from fear focuses on physical security of people and that of the state. On the other hand, freedom from want emphasises meeting the basic socio-economic needs of individuals and communities. The analytical focus of this article is essentially on whether the SANDF contributed to either, or both, freedom from want and freedom from fear.

\subsection{Securitisation theory as an analytical tool for human security}

The idea of securitisation emerged when a group of scholars, including the authoritative Barry Buzan and Ole Wæver, became concerned with how the concept of security might be rendered useless by simply being appended to a long range of issues under the broadened security discourse emerging towards the end of the Cold War (Peoples and Vaughan-Williams 2010: 75). Human security (as an approach within the critical security studies family) and securitisation theory are linked by the fact that they agree on the constructivist nature of security, they oppose the state as the referent object and they concur on the broadening of the security agenda (Peoples and Vaughan-Williams 2010: 23). The distinguishing feature is that securitisation theory is inclined to 
examine the process how a security issue comes to be categorised as such. This provides an opportunity to understand security as a context specific phenomenon it is in contrast to just labelling any assortment of issues as 'security' matters which as a deficiency associated with human security.

Certainly, Hough (2003: 1) contends that the problem in South Africa is a lack of precise demarcation of what issue constitutes a national security issue, or when does an article of human insecurity get into the realm of national security to be treated with the urgency it deserves. Yet, using the politics of securitisation and desecuritisation can generate knowledge on who does and resists securitisation on what, how and with what effect (Wæver 2011: 466). In other words, human security as policy tool of governments can be analysed and understood using securitisation theory.

To be sure, securitisation has to do with 'speech acts' in which persons of authority (usually politicians and government bureaucrats) identify an existential threat to a referent object and subsequently act to mobilise emergency measures to mitigate the threat (McDonald 2008: 567). Buzan and Hansen (2009: 214) add that the securitisation process involves a spectrum of steps in which non-politicised issues move to be politicised and ultimately securitised when emergency measures are instituted. Examples of emergency measures by the state could include the use of violence, a veil of secrecy, or circumventing normal public policy process (Sjostedt 2007: 238). Because securitisation implies certain actions following speech acts (and written texts), the strategic defence posture and function that were performed by the SANDF will be scrutinised to see if they advanced the cause of human security and/or state security.

Save for being a useful analytical framework for the security analyst, securitisation theory is a valuable and powerful tool which government can use to lift a politicised issue into the realm of security. Through the securitisation process, state resources can be mobilised to expeditiously deal with those challenges affecting people. Professional militaries are renowned for effectively executing tasks assigned to them. It is not difficult, for example, to imagine the SANDF timely delivering infrastructure like roads and bridges to rural South Africa if all systems and proper procedures are in place.

The South African government may have missed an opportunity to use the securitisation model when 13 soldiers were killed in combat 
with Seleka rebels in the Central African Republic (CAR) in March 2013. Instead of clearly framing the deployment to the CAR and the unfortunate incident as a matter of national security, the government offered little by way of explanation. This left open a space for critics like Saunders (2013: 154) to question the government's decision to allow the SANDF in the Democratic Republic of Congo (DRC) to be part a more dangerous and offensive peace enforcement mission only six months after the CAR incident.

\subsection{Indicators for assessing the SANDF's praxis}

The possible disjuncture between principle and practice, between lexis and praxis, will be evaluated by an assessment of two indicators. Firstly, the strategic defence posture will be explored with regards to how the democratic government has used the SANDF as a tool in its relations with other states on the African continent. The operational definition of strategic defence posture used in this article is derived from Till's (2008: 95) exposition that strategy is fundamentally about how nation states use the military, both during war and peacetime, to achieve political objectives including in its relations with other states. Strategic defence posture viewed in this manner is relevant as an indicator because one of the leading principles of human security is its universal character (UNDP 1994: 22). This implies that those who subscribe to human security have to care about other people in the world regardless of where they are. Africa is thus chosen as a unit of analysis because South Africa has boldly admitted that its foreign policy deliberately prioritises the continent (Ebrahim 2012: 131; Nkoana-Mashabane 2013).

The second indicator to be scrutinised is that of functions performed by the SANDF. This line of inquiry is informed by the perennial question asked by security scholars as to what ought to be the role of the military in society, especially in the context of developing countries with pressing socio-economic imperatives. Debate on this issue was dichotomised along two camps, the 'doves' and the 'hawks', upon South Africa's democratisation (Esterhuyse 2010: 4; Vrey 2004: 96). The former cohort wanted the SANDF to play a minimal traditional role as they advocated for defence budget cuts. On the other hand, the hawks wanted the traditional capacity of the military to be maintained to guarantee state security and guard the country against external aggression. State security has been defined as the protection of a particular territory, its 
independent sovereignty and the institutions which regulate interactions of group within the territory (Hough 2003: 8-9).

\section{South Africa's evolving strategic defence posture}

\subsection{The policy framework}

Prior to 1994, the role of the defence force in South Africa was to protect a minority section of the population and to guard the country's borders with an iron fist. The military also had a notoriously offensive posture as it conducted active operations in neighbouring states while making significant inputs to domestic political and security decision making (Esterhuyse 2010: 3). Booth and Vale (1995: 286) add that the realism that shaped South Africa's conception of security was not good for Southern Africa in the 1980s. It is estimated that during this period more than a million people lost their lives and that the price tag of this 'destabilisation' policy was in the region of US\$62.42 billion.

In the setting of the democratic era, President Mandela laid the official foundation of South Africa's human security paradigm in his historic inaugural address to parliament on 24 May 1994. Mandela (1994) said, "my government's commitment to create a people-centred society of liberty binds us to the pursuit of the goal of freedom from want, freedom from hunger, freedom from deprivation, freedom from ignorance, freedom from suppression, and freedom from fear".

Apart from declarations by top leaders, another way to understand perceptions driving a country is to examine its policies. The most authoritative defence policies of South Africa's democratic epoch include: the Constitution (1996), the White Paper on National Defence (1996) and the subsequent Defence Review (1998), as well as the White Paper on South African Participation in International Peace Missions (1999). These seminal documents are renowned for the extensive consultative nature of their formulation which is a vital ingredient for any democracy. Kynoch (1996: 450) labels their precursor, the 1995 draft White Paper on Defence, as a "progressive document" for putting people at the centre of the security agenda.

The conduct and posture of the SANDF is principally guided by section 200(2) of the Constitution. This article enjoins that "the primary 
object of the defence force is to defend and protect the Republic, its territorial integrity and its people in accordance with the Constitution and the principles of international law regulating the use of force" (RSA 1996a: 117). South Africa's choice of a fundamentally defensive posture was partly influenced by the policymaker's desire to rid the country of its shameful past when it destabilised neighbouring states during apartheid.

Another central defence policy document during South Africa's democratic transition, the White Paper on Defence, outlined transformation as an overarching theme contextually rooted three determining factors. These were the history of the armed forces, the new strategic milieu (internationally, regionally, and domestically) as well as the advent of democracy. In addition, transformation of the defence force was to be guided by 16 principles mainly derived from the Constitution. These principles were to have implications for the functioning and posture of the SANDF as suggested by two of them which were stated as thus:

- National security shall be sought primarily through efforts to meet the political, economic, social, and cultural needs of South Africa's people, and through efforts to promote and maintain regional security.

- South Africa shall pursue peaceful relations with other states. It will seek a high level of political, economic and military cooperation with Southern African states in particular (RSA 1996: 7-8).

In sum, national security in South Africa was to be sought by pursuit of security of the people, including those beyond the country's borders. This was to be achieved by a non-aggressive and collaborative approach to security and development with regional partners. This collaborative stance was reiterated in the White Paper on South African Participation in International Peace Missions. A core aspect of this document relates to assisting people when conflict arises in foreign lands as critical to South Africa's national interest. Because of its own negotiated settlement in ending apartheid the preferred mode of conflict resolution South Africa would use was negotiation. However, since each conflict has its own dynamics, sending the SANDF on peacekeeping or peace enforcement missions was an option (RSA 1999: 5). 


\subsection{Manifestation of strategic posture}

Irrespective of the means used to resolve conflict on the continent, the overarching theme is that South Africa's officialdom securitised regional stability as it was recognised that internal disputes in one state may have spill over effects on neighbouring countries. Consequently, there was an argument that South Africa could not be an 'island' of prosperity and stability in a sea of poverty and instability (Mapisa-Nqakula 2014; Mbeki 2002). Even much earlier in its tenure, the democratic government was of the view that "domestic peace and stability will not be achieved in a context of regional instability and poverty. It is therefore in South Africa's long-term security interests to pursue mutually beneficial relations with other SADC states and to promote reconstruction and development throughout the region" (RSA 1996: 20). The idea of addressing poverty and pursuing reconstruction and development is compatible with human security thinking.

The rationale of treating each conflict on its merits led South Africa to behave differently in different scenarios and consequently having a divergent strategic defence posture. Diplomatic instruments like good offices and mediation as well as military instrument have all been used in South Africa's pursuit of peace and stability, and by extension the quest for human security. Yet, some have interpreted South Africa's security engagements with Africa and the world as indicative of "schizophrenic" foreign policy (Bell 2007: 17) and "without strategic context" (IISS 2013: 489). To be fair to South Africa's defence posture, it must be taken into cognisance that strategic actions are bound to be inconsistent due to the contingent nature of the international political system and security dilemmas.

The imperative to formulate policies suitable for democracy during Mandela's incumbency meant the SANDF was not utilised to optimal capacity, particularly in the regional and international spheres. South Africa opted for the more pacific mode of dialogue when a constitutional crisis erupted in Lesotho in October 1994. Again, and contrary to popular belief, South Africa first attempted to use diplomacy after contested election results caused political problems and riots in May 1998 (Barber 2004: 111). It was only when there was a reported coup d'état that the SANDF was swiftly deployed to Lesotho in September 1998.

The military intervention in Lesotho drew criticism of some polit- 
ical analysts and civil society organisations that were of the view that Pretoria's actions were motivated by national interests and regional hegemonic ambitions. This allegation is given credence by the operational decisions of the mission. Upon arrival in Lesotho, the armed South African forces first went to secure valuable water resources at Katse Dam and only later proceeded to deal with mutineers and protesters in the capital Maseru (Likoti 2007: 257; Neethling 1999: 2). Could it have been that South Africa's national interests in the form of economic benefits accruing from the water project mattered more than the plight and lives of distressed Basotho natives? If that was the case, then it was clearly irreconcilable with human security values that South Africa subscribes to and which enjoin it to prioritise people.

The difficulty to operationalise a strategic orientation like 'defensive' posture was also illustrated when South Africa was called upon to help in the DRC when President Laurent Kabila asked for military assistance to quell a rebellion aimed at usurping him from power in August 1998. Nathan (2004: 7) gives an account of how the 'pacific' South Africa first sought a political solution in the DRC but in the end the diktats of realpolitik compelled Mandela to consider the military option in order to forge unity within the Southern African Development Community (SADC).

South Africa subsequently grew and improved from when it committed to contributing one battalion to peace support operations at any particular time as envisioned in 1998 (RSA 1998: 54). By the time Mbeki took over the levers of power in 1999, a clearer picture about the role of the military had emerged. It was decided that the SANDF could be used as a foreign policy tool (Esterhuyse 2010: 11). Guided by the defensive posture doctrine, which did not change under successive administrations since 1994, the SANDF has played a stellar role on the continent in pursuit of peace and security.

"African solutions to African problems" is a philosophical outlook that South Africa tried to bring to life not only with words but in deeds as well, especially under Mbeki's administration. The SANDF took part in 14 peace missions and other deployments comprising of 83496 members between 1999 and 2014, while going forward South Africa was amongst the first countries to volunteer its troops to the envisaged African Standby Force (Mapisa-Nqakula 2014). The fact that South Africa became the tenth largest contributor to United Nations (UN) peace missions at some point (RSA 2014: 0-3) serves as further valida- 
tion of the country's commitment to peace. In the financial year 2013/14 alone, South Africa embarked to spend R585 million on maritime security within SADC (Mapisa-Nqakula 2013). This was to fight piracy in the region and to ensure security of the economic zone.

\subsection{The SANDF in peace missions and other operations}

As alluded to in the preceding section, South Africa began to accelerate use of the SANDF as an instrument of foreign policy circa 1999. This was partly due to the grand vision of an African Renaissance advocated by the newly elected President Mbeki. Prior to 1999, external deployment of the SANDF was limited to small specialist teams in support of UN missions as well as humanitarian relief operations following disasters. Some of the relief operations undertaken by the SANDF include: humanitarian aid in the form of provision of medical supplies, supply of food and clothing after the genocide in Rwanda in 1994-1995; recovery of victims of a sunken ferry in Lake Victoria, Tanzania in 1996; search and rescue operations following heavy snowfall in Lesotho in 1996; and food relief operations in Mozambique in 1997 and again 1999 (Heinecken 2002: 73).

Clearly, one of the ways South Africa hoped to advance the cause of human security, at home and abroad, was through participation in African peace missions and operations other than war. However, what public officials pronounced in speeches and intended to do was not always easily implementable in practice. For example, then Deputy Minister of Defence Nozizwe Madlala-Routledge spoke to the concept of "developmental peacekeeping" and highlighted the need for military personnel, equipment, structures, planning capability, and training to be used to ensure human security not only in South Africa but on the continent as well. Madlala-Routledge (2003) elaborated that the SANDF must have an approach which "will ensure that the peacekeepers of the future will not only carry a gun, but also a pick and shovel, chalk and duster, and negotiation and conflict resolution skills. As well as keeping the warring factions apart, they will help to rebuild infrastructure, improve health, education, and governance and thus literally start rebuilding the country where they are deployed".

Apart from traditional post-conflict activities like security sector reform, and disarmament, demobilisation and reintegration processes 
(Lekota 2008), one can hardly find evidence of the SANDF systematically rebuilding infrastructure or improving the health and education systems where it deployed as suggested by Madlala-Routledge. Undertaking such generous activities might have been overambitious on the part of the SANDF given its resource and budget constraints as well as South Africa's dire challenges like income inequality, infrastructure bottlenecks, and abject poverty. A more practically tenable scenario would be of the kind Lekota guaranteed when he signed a defence bilateral agreement with Benin. Lekota (2008b) promised that South Africa was ready to offer Benin military skills in engineering which the Beninese forces could use to enhance projects like building schools and bridges in their own country.

On the balance of the evidence and arguments presented thus far, it can be surmised that from a strategic defence posture point of view the SANDF has a mixed record in contributing towards the cause of human security. With regards to freedom from fear, the SANDF has more often than not covered itself in glory. Its success in humanitarian disaster relief operations ranks amongst the best in Africa. In addition, demand for the SANDF to participate in peace missions increased exponentially over the years as many in Africa often appealed to South Africa for help when conflict arose (Schoeman 2000: 56).

A number of reasons explain the demands that have been placed on the SANDF, and which have adversely affected its operational capacity. Firstly, using Kal Holsti's (1970: 245) notion of role conception, it can be concluded that South Africa's policymakers had a perception of the country as a regional leader with certain responsibilities entrusted to it. The White Paper on Foreign Policy boldly proclaims that "since 1994, the international community has looked to South Africa to play a leading role in championing values of human rights, democracy, reconciliation and eradication of poverty and underdevelopment" (RSA 2011: 11). Furthermore, because of the ubuntu philosophy that underpins foreign policy, it is envisioned that "national security would therefore depend on the centrality of human security as a universal goal" (RSA 2011: 4). Secondly, as articulated by President Zuma (2011), South Africa's role towards security on the continent is borne out of a duty to return the favour since Africa stood in solidarity with the country and helped to defeat apartheid. Last but not least, South Africa had to help out of moral obligation rooted in its status as an economic powerhouse on the continent (Heitman 2003: 18). 
Despite the principled stance South African authorities took with regards to human security, including beyond its shores, there were several weaknesses with respect to how this was pursued. For instance, Hendricks (2015: 9) makes the critical and illuminating observation that South Africa's conflict management strategy in Africa is state-centric and "falls short of its intended objective of promoting human security". Hendricks (2015: 12) further contends that South Africa's "narrow focus on the state and war elites leaves key conflict generating issues unresolved and reinforces militarised authoritarian state structures. It has therefore paid lip service to creating more inclusive conflict management processes". This conclusion came after Hendricks studied the model which brought about South Africa's "success stories" in African conflict management, using Burundi and the DRC as case studies. The model involves the elements of: bringing belligerents together to sign a peace agreement; establishment of an interim inclusive government; deployment of peacekeepers; multiparty elections; and post-conflict reconstructions programmes focusing on state institutions and infrastructure.

It is evident that at a strategic level the military in South Africa has been used as part of a toolkit, along with instruments like diplomacy and economic resources, to pursue more of state security than human security on the continent. Yet, there were challenges at an operational level for the SANDF. Jørgensen (2007: 42) points out that although the securitising move in terms of the government identifying security problems in countries like the DRC as a threat to South Africa's interests there was no subsequent circumvention of political processes or allocation of extra resources in mitigation. This rendered the securitisation process incomplete.

More seriously, failure to adequately resource the SANDF compromised its operational capacity when it was deployed to the DRC with insufficient equipment, low standards of training and discipline in 2005-2006 (Jørgensen 2007: 54). The problem of adequate budgeting and resources has not been resolved and is so dire that MapisaNqakula (2016) warned during her budget vote that it could negatively "impact on operational outputs, including loss of life". The issue of resource constraints is but one component of a conglomerate of issues that South Africa should be grappling with as identified by the chairperson of the defence review committee, Roelf Meyer, and his colleagues. According to Meyer (et al 2013), the bigger conundrum is the disparities 
between defence mandate, functions, international commitments, technology and the budget. This section has dealt with the SANDF's international commitments but as its former Chief, General Nyanda (2001: 55) once alluded, it still had domestic tasks demanding its attention. The next section will assess functions of the SANDF in as far as they contributed to human security at home.

\section{The SANDF's human security functions at home}

Given the ominous resource deficiencies, developing countries like South Africa have to be circumspect with how they use an instrument like the armed forces. This is no less a moral dilemma than it is a practical consideration. Williams (2002: 212) cautions that the tendency of developing countries to have the primary function of the armed forces as protection of sovereignty and territorial integrity must be reconsidered. The advisory challenges South Africa's constitution when it proclaims that "the primary object of the defence force is to defend and protect the Republic, its territorial integrity and people" (RSA 1996a: 117). This line functional responsibility was allocated in the 1996 Defence White Paper and was reaffirmed in the 2014 Defence Review. The SANDF can also perform secondary functions which are nonmilitary tasks performed outside the primary function. The White Paper gives examples of secondary tasks to include, inter alia, disaster relief operations, the provision and maintenance of essential services as well as the protection of marine resources (RSA 1996: 21-25).

There are good anecdotes of the SANDF performing secondary tasks. The SANDF played its social responsibility part in 1996 when the South African Air Force (SAAF) saved 300 lives during floods while the South African Military Health Service (SAMHS) provided medical services at provincial hospitals when there was labour unrest (Haefele 1998: 53). The military also acquitted itself in supporting the police in fighting crime and political violence as well as assisting in voter registration and securing elections (Mandela 1994b; 1996; 1997).

In addition, the military's contribution to crime prevention along South Africa's borderline was nothing short of excellence if one considers the statistics from the SANDF Operational Division (in Haefele 1998: 50-52). The statistics reveal that 26746 arrests related illegal to 
border crossings were effected while 1182 illegal weapons were recovered in only seven months (1 January to 31 July 1997). In the comparative period in 1996, illegal border crossing arrests and recovery of illegal weapons respectively totalled 26961 and 1734 . Other operational successes included the confiscation of drugs as well as stolen cars and livestock.

Fighting crime was particularly important and politically contentious for Mandela's administration. Crime during this time remained "the greatest threat to individual security" as levels were "amongst the highest in the world" (Cawthra 2003: 50). Mandela (1997) even identified criminal networks operating at some of the country's commercial entry points as a threat to national security. Mandela (1996) had also earlier indicated that "the national effort to improve the quality of life of the people means also that each citizen and each community should enjoy security in the home, at work and in the street". In other words, if South Africans were to be 'free from want' then this was to be enjoyed in an environment 'free from want'. Ultimately, the issue of crime epitomised a 'new' security matter that was successfully securitised in South Africa. The issue was first politicised and government authorities employed emergency measures of deploying the army in response. Thus, not only did the SANDF contribute to one aspect of human security, freedom from fear, but it simultaneously ensured state security.

The SANDF was able to perform as well as highlighted even though secondary tasks were never catered for in terms of organisational structure, resources and equipment (Esterhuyse 2012: 235; Ferreira and Henk 2009: 507). The observation by Esterhuyse (2012: 235) that "very few of the South African military programmes can be considered human security related" was given credence by the policy statement that "inappropriate use of military forces in non-military activities is economically inefficient" (RSA 1996: 25). Regardless, the SANDF did perform secondary and some human security related tasks using the unique capabilities and inherent collateral utility deriving from the primary capacity. However, the mode of increasing responsibilities on the military to do this and that without requisite resources adversely affected operational efficiency and is unsustainable. The situation became so desperate that Esterhuyse (2010: 20) warned that the SANDF faced "a future in which it will be asked to do everything for everybody and in reality will be able to do nothing for nobody".

Unfortunately, successful securitisation did not happen with the 
other important element of human security. This is the freedom from want element significantly composed of socioeconomic challenges confronting ordinary people. Indeed, problems like poverty, unemployment, poor education, and lack of housing amongst others were securitised when it was declared that they pose "the greatest threats to the South African people" (RSA 1996: 6). However, the securitising move was incomplete as security organs were not given extra resources or a legal mandate to deal with these perceived threats.

Perhaps the securitising move was incomplete because as Jensen and Buur (2007: 45) highlight, political parties who as the representatives of the people in parliament had authority to 'speak' security, agreed on the securitisation of socioeconomic problems afflicting society but they differed on possible solutions. Mabanga (2013: 97) also found that the role of security organs like the military in handling non-military threats was not properly defined in South Africa. The SANDF consequently played an indirect and supportive role across various sectors where circumstances allowed.

On the economic front, as an example, the Navy patrolled the coastline to ensure maritime law enforcement and prevent illicit activities like pollution, piracy and smuggling of drugs and weapons (Simpson-Anderson 1997). In addition, procurement of weapons and related equipment by South African security organs from the domestic arms industry totalled R2 663 billion in the financial year 1996/97 (RSA 1998a: 309) while the DoD employed a massive 90000 people instead of the recommended 70000 (RSA 1998:102).

With regards to education and skills development, a Service Corps was established in 1998 with the objective of arming soldiers not absorbed into the SANDF during integration with vocational skills so they could contribute elsewhere in society. Even members of the community benefited when they received skills development training from the Service Corps while there were also projects related to the health field as well as road construction and water provision related to the Reconstruction and Development Programme (Williams 1998: 32; Vuthela 2003: 35). The SANDF similarly responded to the call of duty by skilling young people through the Youth Foundation Training Programme and Military Skills Development Programme when the government launched the Accelerated and Shared Growth Initiative in 2007 (Vuthela 2006: 28).

Environmental issues are one of the critical components of South Africa's broad security framework (Lekota 2008a). As proclaimed, "the 
environment is a strategic issue in defence, and is awarded a high priority in all dealings in the military sector" (RSA 2002a: 461). Practically, this meant the SANDF was obliged to use the land in its custody for planning and executing military activities with long term implications for the country in mind. The DoD thus in the interest of social justice correctly rationalised land under its custody to use for non-military purposes. Some land was given back as restitution after it was forcibly taken away from communities during apartheid (RSA 2002a: 461). Yet, it is worthwhile to note the remarks of the DoD Chief of Logistics, Major General Ntsibande (in Ndaba 2003: 43) that the SANDF "as an instrument of government policy on security cannot discharge its obligations in terms of the environment in isolation. There are lead agents in government that set the pace and who are by virtue of their respective mandates responsible for directing the achievement of specific national environmental objectives". Ntsibande's remarks are consistent with Shelton's (2004: 32) view that the SANDF is in no position to respond to all human security threats. Only through cooperation with other lead departments can the DoD and SANDF achieve much.

While the SANDF has involved itself in the above cited and other sectors of civic life, Williams (1999: 7) observes that there were those who preferred for the military to mark time and only focus on the primary duty of guarding the country against imaginary external aggressors. Their reasoning was that this would guarantee good civil military relations. The alternative, argued the alarmists, would be a militarised society as the armed forces abandon the barracks to interfere with civil society. However, such fears can be dismissed on the basis of a finding that South African civil-military relations have so much matured after democratisation that it would be inconceivable for the SANDF to play a "praetorian" role like in the past (Cawthra 2003: 53; Williams 2002: 213).

Furthermore, Williams (2002: 213) found that China, Israel and Senegal are some of the countries that make extensive use of their armed forces in operations other than war. There is therefore no reason why the SANDF cannot contribute in the (re)construction and maintenance of infrastructure, and more importantly in the development of the people in South Africa. This could lead to the attainment of human security as the SANDF would provide not only a secure physical environment but also input into mechanisms to ensure people are free of the those restraints like poverty and joblessness which hinder their full potential and ability to make life choices. 


\section{Conclusion}

Human security is a broad and complex concept that the South Africa has found difficult to operationalise. While the SANDF demonstrated no significant difficulties in executing traditional military roles of ensuring physical security (freedom from fear), it was with the freedom from want component of human security that it struggled or did not perform as optimally. The problem is that on the one hand the socioeconomic needs comprising freedom from want were correctly identified as security threats, yet on the other hand the requisite resources and even legal mandate were withheld for the SANDF to be part of the solution. South African officials tended to lexically and conceptually take state security and human security as equally important but without necessarily capacitating the SANDF to perform both functions. There was consequently an expectation that the SANDF could perform all other secondary tasks, both at home and abroad, using the collateral capacity emanating from the primary functions it was designed for. This ultimately overworked South Africa's military machinery to the point where its operational efficiency was compromised.

Under the circumstances, the SANDF acquitted itself as well as it could when it was deployed on the African continent as part of South Africa's strategic defence posture. However, South Africa's efforts might not have been enough if one considers the critique by Hendricks (2015) that its conflict management strategies on the continent were statecentric and fell short of meeting human security objectives. Similarly to the domestic environment, the SANDF found it easier to do what militaries are traditionally geared for, ensuring state security as opposed to the more eclectic human security when it interacted with other states. How could the SANDF justify building bridges and schools in, say, Benin given the bottlenecks of such infrastructure back at home?

The pragmatism followed by South Africa in collaborating with other African states to meet their security needs at a state level is a model to be followed and must be extended to the human level. Contemporarily, no one state or government entity can on its own ensure the security of the people or the state. Fortunately, South Africa's civilmilitary relations have so soundly evolved in the post-apartheid period that the professional military can be trusted to work in sync with other states, and also other state departments within the country to acceler- 
ate development. A system of checks and balances is in place to allay the concerns of those who fear that an expanded role for the SANDF will militarise society.

The post-Cold War world is characterised by egregious, multidimensional, evolving, and complex security challenges that affect real people more than they do the abstract state. Future scholars are therefore duty bound to give constant research output that is in congruence with the changing nature of security, especially linkages between the security domain and other sectors like health and the economy to mention but two. Scholars of security studies will have to collaborate in multidisciplinary studies with experts from other fields, and also engage with state officials for a comprehensive understanding of security. Perhaps the knowledge output emerging from this research will find viable means of incorporating the voice of the people into the useful and powerful securitisation framework such that the gap between lexis and praxis is closed. When all is said and done, security and human security in particular, is fundamentally about responsiveness, accountability, and transparency in governance. The people must come first in whatever government and researchers do in the name of security.

\section{Bibliography}

Africa, S (2015). "Human Security in South Africa", Strategic Review for Southern Africa, Vol 37, № 1, pp 178-189.

Barber, J (2004). Mandela's World: The International Dimension of South Africa's Political Revolution 1990-1999. Oxford: James Currey.

Bell, T (2007). "No easy answers when it comes to mapping South Africa's influence on Africa", Sunday Independent, 23 December, p 17.

Booth, K and P Vale (1995). "Security in Southern Africa: after apartheid, beyond realism", International Affairs, Vol 71, No 2, pp 285-304.

Buur, L, Jensen, S and F Stepputat (2007). "Introduction", in Buur, L, Jensen, S and

F Stepputat (eds), The Security-Development Nexus: Expressions of Sovereignty and Securitisation in Southern Africa. Cape Town: HSRC Press.

Buzan, B and L Hansen (2009). The evolution of International Security Studies. New York: Cambridge University Press.

Cawthra, G (2003). "Security Transformation in Post-Apartheid South Africa", in Cawthra, $\mathrm{G}$ and $\mathrm{R}$ Luckham (eds), Governing Insecurity: Democratic Control of Military and Security Establishments in Transitional Democracies. London: Zed Books 
Ebrahim, I E (2012). Speech by Deputy Minister of International Relations and Cooperation, Mr Ebrahim I Ebrahim, on the occasion of a public lecture on "Libya, the United Nations, the African Union and South Africa: Wrong Move? Wrong Motives?," Strategic Review for Southern Africa, Vol XXXIII, No 2, pp 128-134.

Esterhuyse, A (2010). "Getting the job done: Transformation in South African Military", Strategic Review for Southern Africa, Vol XXXII, No 1, pp 1-30.

Esterhuyse, A (2012). "Comparing Apples with Pears: the pre-1994 and post-1994 South African Military Cultures", Journal of Contemporary History: Military History 1912-2012, Vol 37, No 2, pp 224-241.

Ferreira, R and D Henk (2009). "'Operationalising' Human Security in South Africa", Armed Forces and Society, Vol 35, No 3, pp 501-525.

Haefele, B (1998). "The role of the South African National Defence Force (SANDF) in internal security", Strategic Review for Southern Africa, Vol 20, No 1, pp 4157.

Heinecken, L (2002). "Preparing for operations other than war: How equipped is the SANDF to deal with 'soft missions'?", Strategic Review for Southern Africa, Vol 26, No 1, pp 63-90.

Heitman, H R (2003). "Enthusiasm outruns capacity for peacekeeping efforts of South Africa", South African Soldier, October, pp 18-20.

Hendricks, C (2015). "South Africa's approach to conflict management in Burundi and the DRC: Promoting human security?", Strategic Review for Southern Africa, Vol 37, No 1, pp 9-30.

Holsti, K (1970). "National Role Conceptions in the Study of Foreign Policy", International Studies Quarterly, Vol 14, No 3.

Hough, M (2003). "National security and threat perception: When is an issue a national security threat?", Strategic Review for Southern Africa, Vol 25, No 2, pp 1-21.

International Institute for Strategic Studies (IISS) (2013). The Military Balance 2013. London: Routledge.

Jørgensen, T (2007). "You do need a stick to be able to use it gently: The South African Armed forces in the DRC", in Buur, L, Jensen, S and F Stepputat (eds), The Security-Development Nexus: Expressions of Sovereignty and Securitisation in Southern Africa. Cape Town: HSRC Press.

Kynoch, G (1996). "The Transformation of the South African Military", The Journal of Modern African Studies, Vol 34, No 3, pp 441-457.

Lekota, M (2008). "RSA: Lekota: Parliamentary media briefing on Programme of Action for International Relations, Peace and Security (IRPS) cluster", 13 February 2008. (Available at: http://www.polity.org.za/article/sa-lekotaparliamentary-media-briefing-on-programme-of-action-for-internationalrelations-peace-and-security-irps-cluster-13022008-2008-02-13, last accessed 


\section{August 2015.)}

Lekota, M (2008a). "Address by Minister of Defence, Hon M.G.P Lekota on the occasion of the Defence Budget Vote". (Available at: http://www.dod.mil.za/ ministry/speeches/BUDGET\%20SPEECH\%202008\%20final.pdf, last accessed 1 February 2015.)

Lekota, M (2008b). "Signing of Agreement between the Governments of the Republic of South Africa and the Republic of Benin", 24 June. (Available at: http://www.polity.org.za/article/sa-lekota-signing-of-agreement-between-thegovernments-of-the-republic-of-south-africa-and-the-republic-of-benin24062008-2008-06-24, last accessed 2 August 2015.)

Likoti, F J (2007). "The 1998 Military Intervention in Lesotho: SADC Peace Mission or Resource War?", International Peacekeeping, Vol 14, No 2.

Mabanga, S P (2013). "South Africa's External Threat Perception: 1994-2012", Master of Security Studies Dissertation. Pretoria: University of Pretoria.

Madlala-Routledge, N C (2003). "Address of the Deputy Minister of Defence, Ms NC Madlala-Routledge, MP, Awards Ceremony: Faculty of Military Science, Military Academy, Saldanha", 9 December. (Available at: http:// www.polity.org.za/article/madlalaroutledge-faculty-of-military-science-awardsceremony-09122003-2003-12-09, last accessed 2 August 2015.)

Mandela, N (1994). "State of the Nation Address", 24 May. (Available at: http:// mandela.gov.za/mandela_speeches/1994/940524_sona.htm, last accessed 2 June 2015.)

Mandela, N (1994b). "Opening Address by President Nelson Mandela in the President's Budget Debate after 100 days in Office", 18 August. (Available at: http://mandela.gov.za/mandela_speeches/1994/940818_budgetopen.htm, last accessed 15 June 2015.)

Mandela, N (1996). "State of the Nation Address", 9 February. (Available at:http:// mandela.gov.za/mandela_speeches/1996/960209_sona.htm, last accessed 2 June 2015.)

Mandela, N (1997). "State of the Nation Address", 7 February. (Available at:http:// mandela.gov.za/mandela_speeches/1997/970207_sona.htm, last accessed 2 June 2015.)

Mapisa-Nqakula, N (2013). "Introduction to National Assembly Debate on Budget vote 22: Defence and Military veterans". (Available at: http:/hww.gov.za./ speeches/view.php?sid=36705\&tid=107903, last accessed 17 April 2014.)

Mapisa-Nqakula, N (2014). "Media statement by the Minister of Defence, Ms Nosiviwe Mapisa-Nqakula during peacekeeping and post conflict reconstruction and development media briefing" 31 March. (Available at: http://www.gov.za/ speeches/view.php?sid=44784, last accessed 17 April 2014.)

Mapisa-Nqakula, N (2016). "Defence Budget Vote". (Available at: http://www.gov.za/ speeches/minister-nosiviwe-mapisa-nqakula-defence-and-military-veterans- 
dept-budget-vote-201617-11, last accessed 28 June 2016.)

Mbeki, T (2002). "President of the Republic of South Africa, Thabo Mbeki, at the Opening of the World Summit for Sustainable Development", 26 August. (Available at: http://www.un.org/events/wssd/statements/openingsaE.htm, last accessed 20 July 2015.)

McDonald, M (2008). "Securitisation and the Construction of Security", European Journal of International Relations, Vol 14, No 4, pp 563-587.

Meyer, R, Sandall, N, Gibbs, J and T Keketsi (2013). "Living up South Africa's leadership and defence responsibility on the African continent", New Age, 9 April.

Mutimer, D (2008). "Beyond Strategy: Critical Thinking on the New Security Studies", in Snyder, C A (ed), Contemporary security and strategy. Basingstoke: Palgrave MacMillan.

Nathan, $L$ (1991). Riding the tiger: The integration of armed forces and postapartheid military - A working paper series. University of the Western Cape: Centre for Southern African Studies.

Nathan, L (2004). "The absence of common values and failure of common security in Southern Africa, 1992-2003", Crisis States Research Centre. Working Paper No 50: pp 1-29.

Ndaba, D (2003). "Ensure that military activities do not harm the environment", South African Soldier, October, pp 42-43.

Neethling, T (1999). "Military Intervention in Lesotho: Perspectives on Operation Boleas and Beyond", The Online Journal of Peace and Conflict Resolution, Issue 2.2.

Nkoana-Mashabane, M (2013). "Budget vote speech by Minister of International Relations and Cooperation". (Available at: http://www.gov.za/speeches/view/ php?sid=36948, last ccessed 25 June 2015.)

Nyanda, S (2001). "Restructuring the SA military: Between domestic imperatives and external obligations", South African Journal of International Affairs, Vol 8 , No 2, pp 45-55.

Peoples, C and N Vaughan-Williams (2010). Critical Security Studies: An Introduction. London: Routledge.

Rozborová, L (2013). "Human Security as a Political Strategy: The Road to Peace?: The Role of the EU in Bosnia and Herzegovina". (Available at: http:// urn.nb.no/URN:NBN:no-37357, last accessed 06 October 2014.)

RSA (1996). White Paper on National Defence of the Republic of South Africa. Pretoria: Government Printers.

RSA (1996a). The Constitution of the Repubic of South Africa: Act 108 of 1996. Pretoria: Government Printers.

RSA (1998). South African Defence Review. Pretoria: Government Printers.

RSA (1998a). South Africa Yearbook 1998. Pretoria: Government Printers. 
RSA (1999). White Paper on South African Participation in International Peace Missions. Pretroria: Government Printers.

RSA (2002). South African Yearbook 2001/02: Safety, Security and Defence. Available at: http://www.gcis.gov.za/sites/defaultfiles/docs/resourcecentre/ yearbook/2002/chap18.pdf, last accessed 1 August 2015.)

RSA (2014). South African Defence Review. Pretoria. Government Printers.

Saunders, C (2013). "Military Intervention in conflict situations in Africa: Thoughts on South Africa's Role", Strategic Review for Southern Africa, Vol 35, No 2, pp 152-156.

Schoeman, M (2000). "South Africa as an emerging middle power", African Security Review, Vol 9, No 3, pp 47-58.

Seegers, A (2010). "The new security in democratic South Africa: A cautionary tale", Conflict, Security and Development, Vol 10, No 2, pp 263-285.

Shelton, G (2004). The South African National Defence Force (SANDF) and President Mbeki's Peace and Security Agenda: New roles and mission. Braamfontein: Institute for Global Dialogue.

Simpson-Anderson, R (1997). "Annual Policy Review of the South African Navy, 1996", Diplomats and Defenders, Published Monograph Number 9.

Sjostedt, R (2007). "The Discursive Origins of a Doctrine Norms, Identity and Securitisation Under Harry S. Truman and George W. Bush", Foreign Policy Analysis, Volume 3.

Southall, R (2010). "The South African Development Model: Hitting against the Limits?", Strategic Review for Southern Africa, Vol 32, No 2, pp 69-92.

Snyder, C A (2008). "Contemporary Security and Strategy", in Snyder, C A (ed), Contemporary security and strategy. Basingstoke: Palgrave MacMillian.

Till, G (2008). "The evolution of strategy and the New World Order", in Snyder, C A (ed), Contemporary security and Strategy, $2^{\text {nd }}$ edition. Basingtoke: Palgrave Macmillian.

UNDP (1994). Human Development Report. New York: Oxford University Press.

Very, F (2004). "Paradigm Shifts, South African Defence Policy and the South African National Defence Force: From Here to Where?", South African Journal of Military Studies, Vol 32, No 1, pp 89-118.

Vuthela, N (2003). "Training institution recharged", South African Soldier, April, p 35.

Vuthela, N (2006). "New vision for a modern army", South African Soldier, May, pp 34-35.

Waever, O (2011). "Politics, security, theory", Security Dialogue. Vol 42, No 4-5, pp 465-480.

Williams, R (1998). "Against meta-narratives?: The strengths and weaknesses of modernism within contemporary South African defence thinking", Strategic Review for Southern Africa, Vol 20, No 1, pp 1-40. 
Williams, $\mathrm{R}$ (1999). "How primary is the primary funcition?: Configuring the SANDF for African realities, African Security Review, Vol 8, No 6, pp 70-83.

Williams, $R$ (2002). "Defence in a democracy: The South African Defence Review and the redefinition of parameters of the national defence debate", in Williams, R, Cawthra, G and Abrahams (eds), Ourselves to know: civilmilitary relations and defence transformation in Southern Africa. Pretoria: ISS.

Zuma, J (2011). "Address by President Dr Jacob Zuma on aspects of South African Foreign Policy at the University of Pretoria". (Available at: http://www.anc. org.za/show.php?id=9000, last accessed 2 August 2015.) 